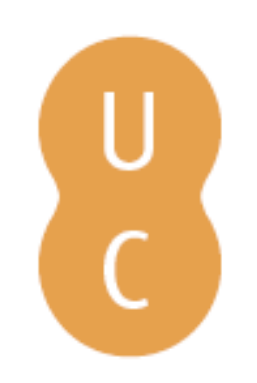

prombalina

\title{
A project to measure and model pyrolysis to improve prediction of prescribed fire behavior
}

\begin{tabular}{ll} 
& Weise, David R.; Fletcher, Thomas H.; Johnson, Timothy J.; Hao, \\
Autor(es): & $\begin{array}{l}\text { WeiMin; Dietenberger, Mark; Princevac, Marko; Butler, Bret; McAllister, } \\
\text { Sara; O'Brien, Joseph; Loudermilk, Louise; Ottmar, Roger; Hudak, } \\
\text { Andrew; Kato, Akira; Shotorban, Babak; Mahalingam, Shankar; Mell, } \\
\text { William E. }\end{array}$ \\
$\begin{array}{ll}\text { Publicado por: } \\
\text { URL } \\
\text { persistente: }\end{array}$ & $\begin{array}{l}\text { Imprensa da Universidade de Coimbra } \\
\text { DOI: }\end{array}$ \\
$\begin{array}{ll}\text { Accessed : } & \text { DOI:https://doi.org/10.14195/978-989-26-16-506_33 }\end{array}$ \\
\hline
\end{tabular}

A navegação consulta e descarregamento dos títulos inseridos nas Bibliotecas Digitais UC Digitalis, UC Pombalina e UC Impactum, pressupõem a aceitação plena e sem reservas dos Termos e Condições de Uso destas Bibliotecas Digitais, disponíveis em https://digitalis.uc.pt/pt-pt/termos.

Conforme exposto nos referidos Termos e Condições de Uso, o descarregamento de títulos de acesso restrito requer uma licença válida de autorização devendo o utilizador aceder ao(s) documento(s) a partir de um endereço de IP da instituição detentora da supramencionada licença.

Ao utilizador é apenas permitido o descarregamento para uso pessoal, pelo que o emprego do(s) título(s) descarregado(s) para outro fim, designadamente comercial, carece de autorização do respetivo autor ou editor da obra.

Na medida em que todas as obras da UC Digitalis se encontram protegidas pelo Código do Direito de Autor e Direitos Conexos e demais legislação aplicável, toda a cópia, parcial ou total, deste documento, nos casos em que é legalmente admitida, deverá conter ou fazer-se acompanhar por este aviso.

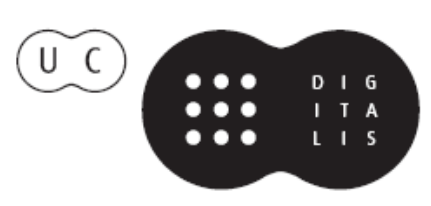




\section{ADVANCES IN}

\section{FOREST FIRE RESEARCH}

\section{8}

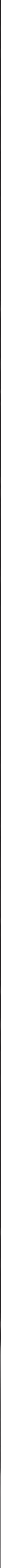




\title{
A project to measure and model pyrolysis to improve prediction of prescribed fire behavior
}

David R. Weise ${ }^{1 *}$; Thomas H. Fletcher ${ }^{2}$, Timothy J. Johnson ${ }^{3}$, WeiMin Hao ${ }^{4}$, Mark Dietenberger ${ }^{5}$, Marko Princevac ${ }^{6}$, Bret Butler ${ }^{4}$, Sara McAllister ${ }^{4}$, Joseph O’Brien ${ }^{7}$, Louise Loudermilk ${ }^{7}$, Roger Ottmar $^{8}$, Andrew Hudak ${ }^{4}$, Akira Kato ${ }^{9}$, Babak Shotorban ${ }^{10}$, Shankar Mahalingam ${ }^{10}$, William E. Mell $^{8}$

${ }^{1}$ USDA Forest Service, PSW Research Station. 4955 Canyon Crest Drive, Riverside, California, USA 92507, \{dweise@fs.fed.us*\}

${ }^{2}$ Chemical Engineering Dept., Brigham Young University. Provo, Utah, USA, \{tom_fletcher@byu.edu\}

${ }^{3}$ Pacific Northwest National Laboratory. Richland, Washington, USA,

\{timothy.johnson@pnnl.gov\}

${ }^{4}$ USDA Forest Service, Rocky Mountain Research Station, \{whao@fs.fed.us\}, \{bwbutler@fs.fed.us\}, \{smcallister@fs.fed.us,ahudak@fs.fed.us\}

${ }^{5}$ USDA Forest Service, Forest Products Laboratory, Madison, Wisconsin, USA, \{mdietenberger@fs.fed.us\}

${ }^{6}$ Mechanical Engineering Dept., University of California-Riverside, Riverside, California, USA, \{marko.princevac@ucr.edu\}

${ }^{7}$ USDA Forest Service, Southern Research Station, Athens, Georgia, USA, \{jjobrien@fs.fed.us\}, \{elloudermilk@fs.fed.us\}

${ }^{8}$ USDA Forest Service, Pacific Northwest Research Station, Seattle, Washington, USA, \{rottmar@fs.fed.us,wemell@fs.fed.us\}

${ }^{9}$ Graduate School of Horticulture, Chiba University, Chiba, Japan, \{akiran@faculty.chiba-u.jp\}

10 The University of Alabama in Huntsville, Huntsville, Alabama, USA, \{Babak.Shotorban@uah.edu,Shankar.Mahalingam@uah.edu\}

\begin{abstract}
Laboratory and field experiments focused on pyrolysis and ignition coupled with sufficient description of fuel characteristics and physics-based modeling are being used to improve our understanding of combustion processes in mixed (heterogeneous) fuel beds managed with prescribed fire in the southern United States. Previous pyrolysis work has typically used ground-up samples, thus eliminating any effects caused by moisture content, fuel particle shape, or heating mode. We are measuring pyrolysis at bench, laboratory and field-scale using intact fuels from living plants. Pyrolysis products being measured include light gases and tars using off-line and real-time spectroscopic instruments. 3-D fuel description, heat transfer to the fuels, and air flow around the fuels are being determined using a variety of intrusive and nonintrusive methods. The ability of high fidelity physics-based FDS, WFDS, and GPYRO3D to reproduce experimental results and to study conditions outside the range of the experimental data is being examined. This presentation will present an overview of the project and the questions being addressed. Preliminary results from initial attempts to measure pyrolysis at field-scale and results from early modeling of pyrolysis of live leaves using coupled GPYRO3D and FDS models are presented.
\end{abstract}

Keywords: FTIR spectroscopy, gas sampling, pyrolysis, convection, gas chromatography, flaming, smoldering, wildland fuels 


\section{Objective}

Wildland fire is an important component of many North American ecosystems and has been used by humans to accomplish various objectives for several thousand years. Prescribed burning in the southern United States is an important tool used by the Department of Defense and other land managers to accomplish several objectives including hazardous fuel reduction, wildlife habitat management, critical training area maintenance, ecological forestry and infrastructure protection. Vegetation is heterogeneous unlike the homogeneous fuel beds assumed by current operational fire spread models. These models do not contain fundamental descriptions of chemical reactions and heat transfer processes necessary to predict fire spread and energy release needed for process-based fire effects models. To improve prescribed fire application, an improved understanding is needed of the fundamental processes related to pyrolysis and ignition in heterogeneous fuel beds. The objective of this project is to address several fundamental questions to improve our understanding and modeling capability of fire propagation in natural fuel beds including 1) detailed description of pyrolysis and the evolution of its products for a greater variety of southern fuels than is currently known, 2) how convective and radiative heat transfer from flames to live fuel particles influences pyrolysis and ignition at laboratory and field scales, and 3) more detailed insight into pyrolysis, combustion and heat transfer processes in wildland fire spread through the use of high-fidelity physics-based models. The questions are being tested with data derived from three activities: 1) characterization of pyrolysis products by measurement for a variety of live and dead foliar fuel particles in laboratory and smallscale field experiments, 2) determination of the effects of convection and radiation heat transfer on pyrolysis, and 3) performance of high-fidelity physics-based modeling of pyrolysis and ignition for bench-scale, wind tunnel and small-scale field experiments. This paper describes the overall project.

\section{Methods}

Laboratory and field experiments focused on pyrolysis and ignition coupled with sufficient description of fuel characteristics and physics-based modeling are being used to improve our understanding of combustion processes in mixed (heterogeneous) fuel beds managed with prescribed fire on DoD installations. Previous pyrolysis work has typically used ground-up samples, thus eliminating any effects caused by moisture content, fuel particle shape, or heating mode. Thermal gravimetric analysis (TGA) coupled with gas chromatography-mass spectrometry (GC-MS) and evolved gas analysis (EGA) have been used for decades to describe the composition and energy content of pyrolysis products. We are measuring pyrolysis at three scales - bench-scale measurements at BYU and the Forest Products Laboratory (FPL), laboratory burn-scale in a wind tunnel at RFL, and small field-scale burns $\left(1600 \mathrm{~m}^{2}\right)$ at Fort Jackson in South Carolina using intact fuels from living plants in natural fuelbeds beneath southern pine forests. 14 plant species were selected (Table 7). One of the dominant shrub species in the pine stands at Ft. Jackson is sparkleberry. Since this plant is deciduous, it causes a significant change to prescribed fire behavior when its foliage is present during the growing season. Sparkleberry was chosen to be the live plant species to link bench-scale measurements to fieldscale measurements. 
Table 1 - Southern plant species used in pyrolysis experiments.

\begin{tabular}{lll}
\hline Common name & Scientific name & Experiment \\
\hline Wiregrass & Aristida stricta Michx. & B \\
Little bluestem & Schizachyrium scoparium (Michx.) Nash & B \\
Inkberry & Ilex glabra (L.) A. Gray & B,W \\
Yaupon & Ilex vomitoria Aiton 'Schelling Dwarf' & B \\
Fetterbush & Lyonia lucida (Lam.) K. Koch & B,W \\
Wax myrtle & Morella cerifera (L.) Small & B \\
Swamp bay & Persea palustris (Raf.) Sarg. & B \\
Sparkleberry & Vaccinium arboreum Marshall & B,W,F \\
Darrow's blueberry & Vaccinium darrowii Camp “Rosa's Blush" & B,W \\
Longleaf pine foliage & Pinus palustris Mill. & B \\
Longleaf pine litter & Pinus palustris Mill. & B,W,F \\
Water oak & Quercus nigra L. & B \\
Live oak & Quercus virginiana Mill. & B \\
Dwarf palmetto & Sabal minor (Jacq.) Pers. & B \\
Saw palmetto & Serenoa repens (W. Bartram) Small & B \\
\hline
\end{tabular}

1. USDA, NRCS. 2018. The PLANTS Database (http://plants.usda.gov, 10 January 2018). National Plant Data Team, Greensboro, NC 27401-4901 USA; Radford, A.E., Ahles, H.E., Bell, C.R. 1968. Manual of the vascular flora of the Carolinas, University of North Carolina Press, Chapel Hill, NC

2. B - bench, $\mathrm{W}$ - wind tunnel, $\mathrm{F}$ - field

\subsection{Bench-scale}

In order to perform calculations related to gas and tar composition as well as modeling the plants with physical fire behavior models, many chemical and physical properties of the plant material in Table 7 were determined using a variety of methods. Because some live leaves will undergo enzymatic hydrolysis when plucked and some live leaves will emit significant combustible volatiles at elevated temperatures below the usual oven dry temperatures of $105{ }^{\circ} \mathrm{C}$, samples were collected and immediately vacuum dried at $45{ }^{\circ} \mathrm{C}$. Proximate and ultimate analysis, and compositional content of live leaves were determined by various standard methods. A special holder equipped with fine thermocouples is being used in the cone calorimeter to determine properties such as thermal conductivity (Figure 53).

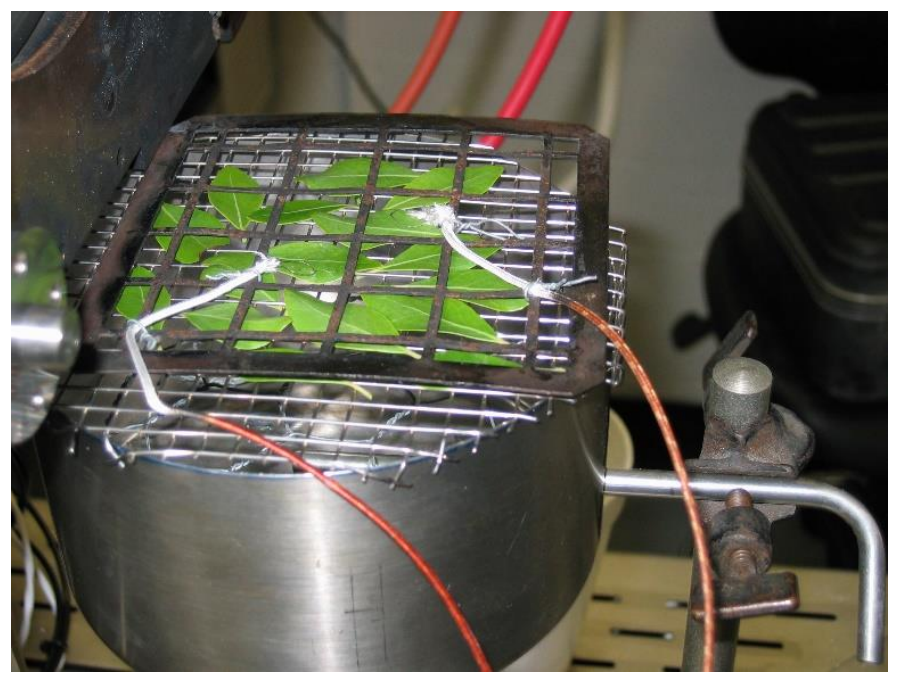

Figure 1 - Specialized holder used for foliage samples in cone calorimeter. 
A flat-flame burner (FFB) apparatus was used to study pyrolysis of foliar samples from the plants in Table 7. (Details of the apparatus and initial results of the tests will be presented by Fletcher et al. (2018) in this conference.) The interested reader is referred to Safdari et al. (2018). In addition to the offline analysis associated with the FFB, a nitrogen purged Bruker Tensor 37 FTIR spectrometer ${ }^{1}$ was deployed to provide real-time measurement of gaseous pyrolysis products by collecting a gas sample every 1.46 seconds (Figure 54). The spectrometer was equipped with a glow bar source, potassium bromide $(\mathrm{KBr})$ beamsplitter and a liquid nitrogen cooled mercury cadmium telluride (MCT) detector. The spectral resolution was $1 \mathrm{~cm}^{-1}$ with the number of scans set to 1 for flowing measurements and 1024 for static measurements. The acquisition mode was set to double-sided, forward-backward. For the Fourier transform, the apodization function was Blackman-Harris 3-Term with a zerofilling factor of 4, and the phase correction mode was Mertz (Mertz 1967). The gas sample was pumped into a White cell (Bruker Optics, A136/2-L) with an effective path length of $8 \mathrm{~m}$. FTIR spectroscopy has been used extensively to characterize smoke emissions from wildland fuels (e.g. Yokelson et al. 1996). Briefly, spectra analysis was carried out using the program Malt5 (Griffith 1996) with $50^{\circ} \mathrm{C}$ reference spectra from the PNNL database (Johnson et al. 2006) and absorption lines from HITRAN. The FTIR method allows for the simultaneous quantification of multiple analytes at the same time; up to two dozen species can have their absolute concentration (and hence fluxes) quantified.

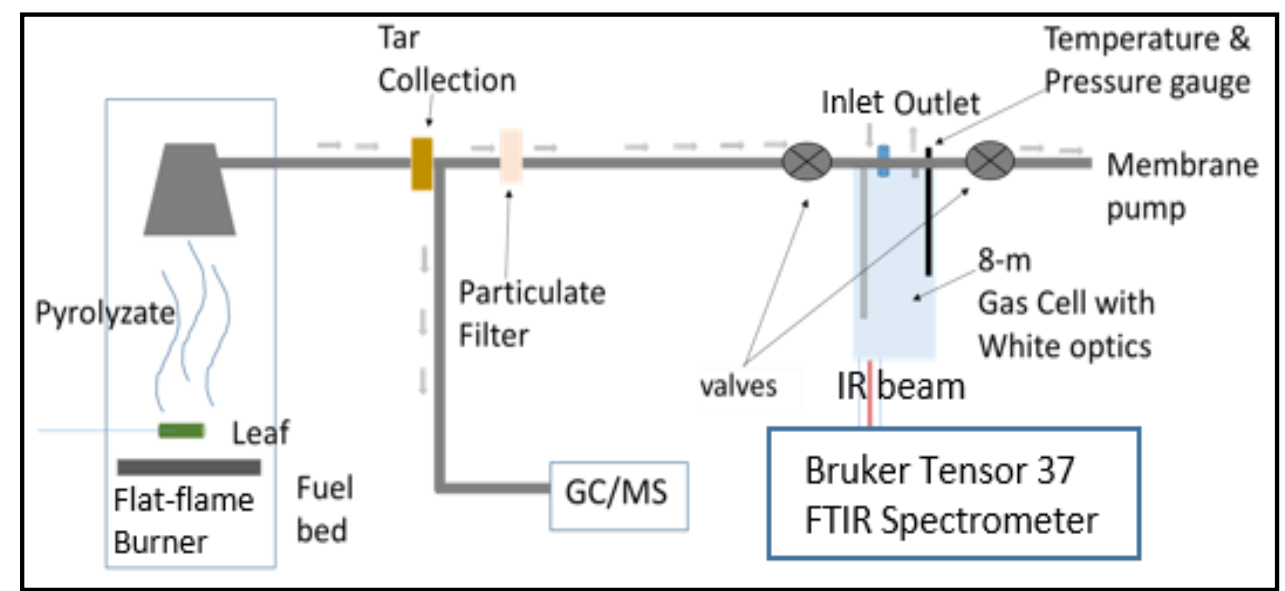

Figure 2 - FTIR spectrometer setup used in conjunction with flat-flame burner to provide real-time measurement of gaseous pyrolysis products.

\subsection{Wind tunnel}

Seventy-three experimental fires have been burned in a low speed wind tunnel located at the Riverside Fire Laboratory (Cobian-Iñiguez et al. 2017). Fuel beds $2 \mathrm{~m}$ long and approximately $1 \mathrm{~m}$ wide composed of longleaf pine needles and various combinations of fetterbush, sparkleberry, and inkberry (Table 7) were burned with nominal wind speeds of 0 or $1 \mathrm{~m} \mathrm{~s}^{-1}$. Pyrolysis gases are sampled in real-time using a variety of methods and instruments (Figure 55, Figure 56). Note that the Bruker Tensor 37 (T37) is the same device used to determine composition of gases at BYU. For Riverside experiments, the resolution was set to $4 \mathrm{~cm}^{-1}$, the acquisition mode was set to double sided, forwardbackward, the apodization function was Blackman-Harris 3-Term, and phase correction mode was Mertz (1967) with a zerofilling factor of 2. In order to increase temporal resolution, the number of

${ }^{1}$ The use of trade or firm names in this publication is for reader information and does not imply endorsement by the U.S. Department of Agriculture of any product or service. 
scans was set to 1 with continuous measurements to obtain a spectral time resolution of 0.2 seconds. This instrument configuration analyzed gases extracted with a $3 / 8$ " metal tubing probe above a plant during measurements (Figure 56).

The other FTIR instrument used for gas phase measurements was the Bruker OPAG-22, which is an open path gas analyzer. The OPAG was mounted on a tripod on one side of the wind tunnel with the glow bar IR source on the opposite side. The path in between the OPAG and the source was 1.2 meters and it was directly in line with a row of plants (Figure 55). The OPAG is equipped with a $\mathrm{KBr}$ beamsplitter and a Stirling-cycle cooled mercury cadmium telluride (MCT) detector. Interferograms were collected in the range of 4000 to $0 \mathrm{~cm}^{-1}$ at a resolution of $2 \mathrm{~cm}^{-1}$ and at an acquisition mode set to double-sided forward-backward. The number of scans per measurement was set to 1 and the measurements were repeatedly collected to obtain a time profile with a resolution (time between spectra) of 0.53 seconds. Gas samples were pumped into canisters for offline analysis using gas chromatography. An array of 9 stainless steel tubes were inserted vertically into the fuel bed. A sample of the flaming gases was collected in one canister initially from one tube and a sample of pyrolysis gases was collected from the other 6 tubes sequentially as the flame front moved horizontally along the fuel bed.

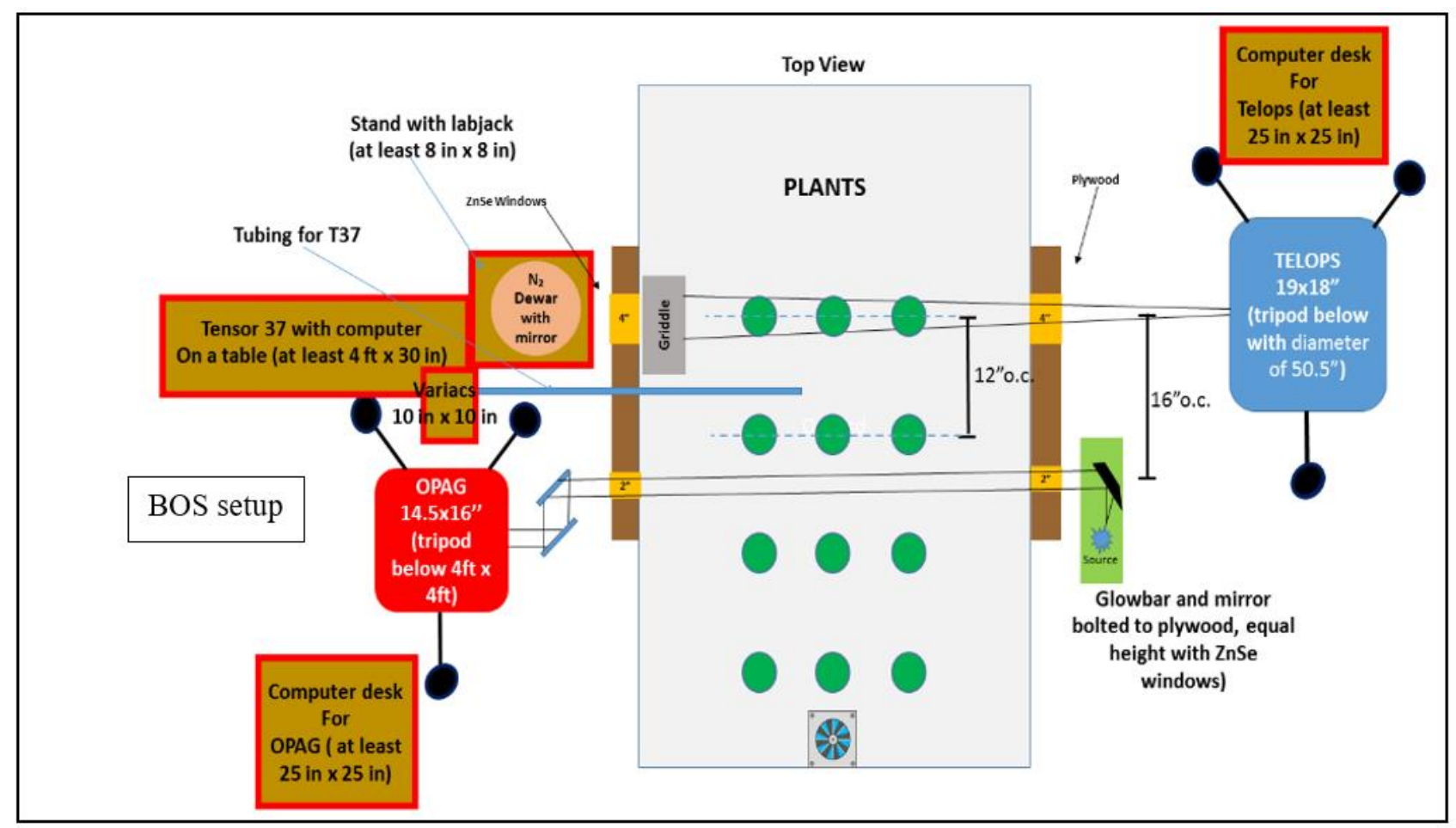

Figure 3 - Setup of 3 instruments used to measure composition of gaseous pyrolysis products in mixed fuel beds of longleaf pine needles and small shrubs.

Mass of a single plant, air temperature and relative humidity within the wind tunnel and in the larger combustion room were sampled at $1 \mathrm{hz}$ during each experimental fire. While we have used a variety of techniques previously to describe the flow field around experimental laboratory fires, the use of smoke tracers and introduced particles was precluded by the gas sampling objective. The TPIV technique (Zhou et al. 2003) could not be used because the large glass windows in the wind tunnel are opaque to the infrared spectrum. The backgound-oriented Schlieren (BOS) approach was selected to determine the flow field in the flame and surrounding the plants (Raffel 2015). The BOS setup (Figure ) was located upwind of the PNNL gas sampling instruments (Figure 55). Total and radiant heat fluxes at the top of the fuel bed were measured using a Schmidt-Boelter type of sensor. A stereo pair of vertical photographs of each fuel bed were taken before and after each experimental fire to develop 3- 
D images of the fuel bed. A longwave infrared (LWIR) camera provided a nadir view of the fuel bed and measured radiance from the fuel bed will be converted into temperature.

\subsection{Pilot Tests - Field}

A trial deployment was performed in May 2017 at Ft. Jackson (Figure ). The forest structure was characterized from Ft. Jackson's existing airborne LiDAR data using a canopy height model (Silva et al. 2016) for the tree overstory and rasterized metrics for the shrub understory (Hudak, Dickinson, et al. 2016; Hudak, Bright, et al. 2016). Destructive fuel sampling methods, 3D measurement of forest and understory vegetation structure using an unmanned autonomous system (UAS), heat flux measurement, and pyrolysis gas sampling were tested during the trial deployment. Burn plots were characterized non-destructively in 3D using terrestrial lidar scans (TLS) and UAS remote sensing tools and destructively in adjacent small fuel sample plots to describe the spatial distribution of fuel elements. TLS of the small fuel plots were collected from multiple view perspectives to characterize $3 \mathrm{D}$ fuel distributions in 10-cm voxels (volumetric pixels), before and after burning. A digital camera mounted on a UAS collected stereo color imagery from overhead perspectives. These metrics serve as independent variables for predicting fuel loads measured in the traditional destructive sample plots pre- and post-fire in units of $\mathrm{kg} \mathrm{m}^{-2}$.
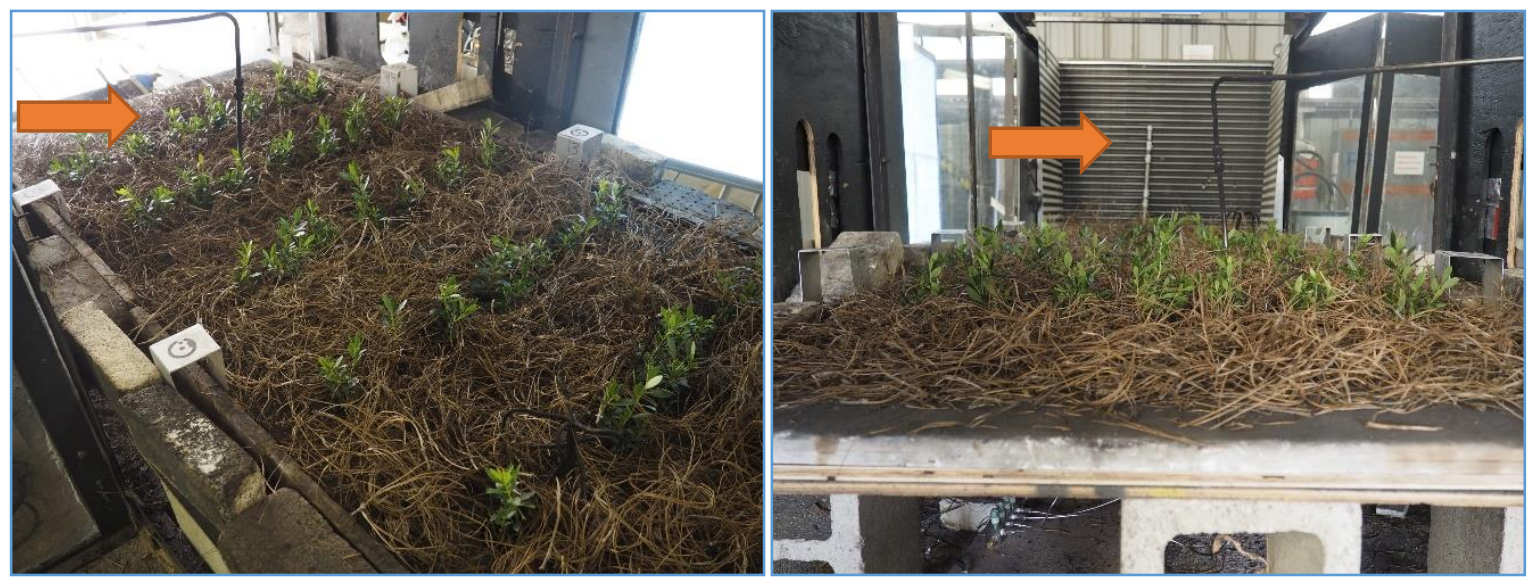

Figure 4 - Fuel bed composed of longleaf pine needles and Lyonia lucida plants. Sample probe to collect pyrolysis gases for the Bruker Tensor 37 is indicated by the arrow.

As pyrolysis gases have never been measured to our knowledge in a field setting, we used a metal probe to sample emitted pyrolysis products very close to the fire. The probe is a variable length (1-4 m) stainless steel tube connected by flexible stainless steel hose to a manifold, from which a canister system, real time gas sensors, and particulate matter (PM) filter samplers draw pyrolysis emissions downstream from the flame. $\mathrm{CO}_{2}$ and $\mathrm{CO}$ were measured in-situ at a $1 \mathrm{~Hz}$ sample rate by their respective sensors. Hydrogen, methane and $\mathrm{C}_{2}-\mathrm{C}_{6}$ alkanes, alkenes and aromatic compounds of smoke samples collected in canisters will be measured by gas chromatography. For the trial deployment, the focus was determining how close personnel could get to the fire in personal protective equipment to capture samples of pyrolysis gases (Figure 57).

\subsection{High-fidelity Physics Modeling}

Prior work by the modeling team has examined the ability of the Fire Dynamics Simulator (FDS) coupled with the GPyro pyrolysis model to simulate pyrolysis, ignition and burning of single leaf particles (Yashwanth et al. 2015, 2016) and the ability of the Wildland Urban Interface extension of FDS (WFDS) to model ignition of many leaf particles (Anand et al. 2017). Significant improvements have been made to the modeling of convective ignition of leaves in the BYU flat-flame burner by Gpyro3D-FDS (Shotorban et al. 2018). One of the improvements included a new rigorous formulation for the calculation of the mean porosities in the computational cells of Gpyro to account for the net 
volume reduction that the condensed (solid) phase experiences within the computational cells during moisture evaporation and pyrolysis. Another improvement was the use of a more advanced pyrolysis mechanism in Gpyro to include the main constituents of biomass, i.e., cellulose, hemicellulose and lignin at virgin and active states in the dry mass. In addition, the modeled leaf now matches the measured manzanita leaf dimensions much better than in the previous modeling work (Yashwanth $e t$ al. 2016). These improvements were necessary in order to model the pyrolysis experiments that are being performed at BYU.

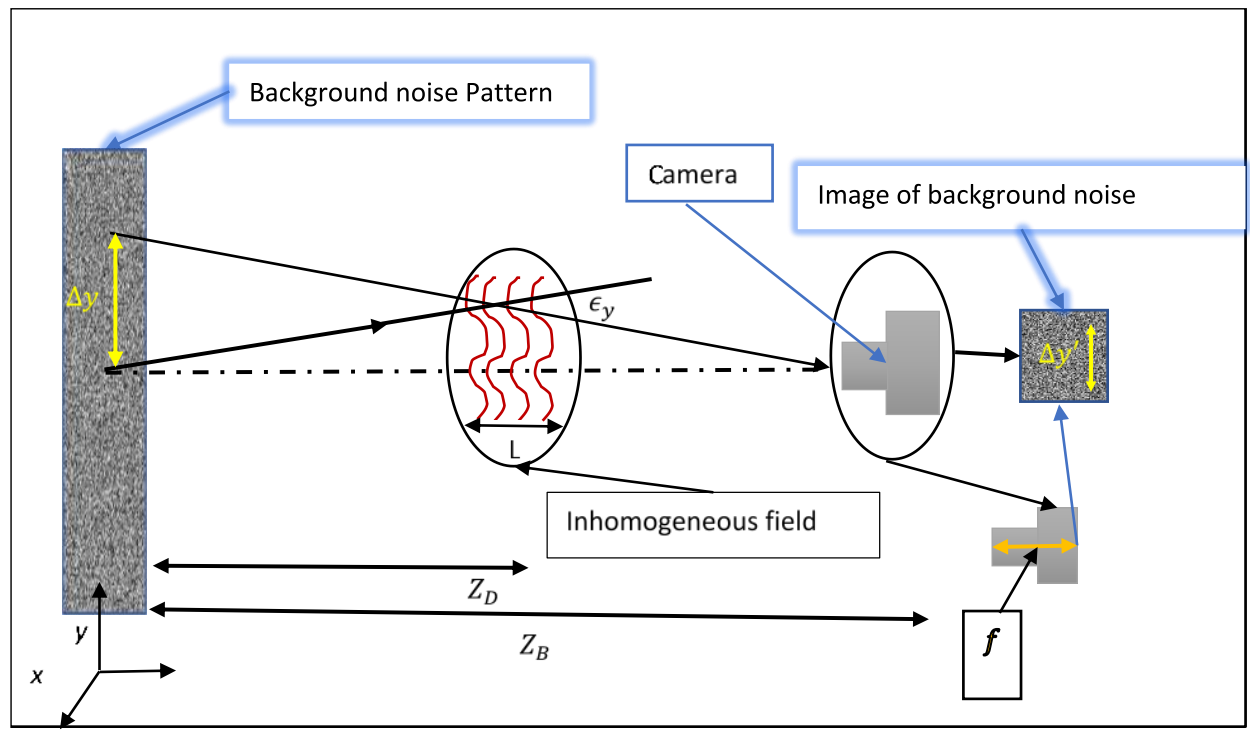

Figure 5 - Simple schematic of background-oriented Schlieren configuration used to nonintrusively estimate the flow field surrounding pyrolyzing plants. $Z_{D}$ is the distance of the flame from the background noise pattern, $Z_{B}$ is the distance of the camera lens from the background, $\epsilon_{y}$ represents the deflection angle caused by the flame-generated distortion, $L$ is the flame zone width, $f$ is the focal length of the camera, $\Delta y^{\prime}$ represents displacement in the camera sensor plane and $\Delta y$ represents displacement in the background plane.

The computational configuration resembles the experimental setup of (Pickett et al. 2010). The burner and the gas phase combustion within the burner was not modeled; the convective heating effect is modeled through the introduction of heated air at $1100{ }^{\circ} \mathrm{C}$ which reduces to around $1000{ }^{\circ} \mathrm{C}$ at $5 \mathrm{~cm}$ above the burner which is consistent with experimental measurements. As the initial condition, the leaf was assumed to consist of moisture and dry mass with standard air in the pores. The initial mass fraction of moisture was determined by the fuel moisture content. Initial dry mass consisted of 33\% cellulose, $33 \%$ hemicellulose and $34 \%$ lignin which differ by $1 \%$ from the experiments. These slight differences had barely observable effect on the simulation results. The initial temperature was set to an ambient temperature of $300 \mathrm{~K}$. A 10-step reaction mechanism (Miller and Bellan 1997) was used for the dry fuel; each of the dry species underwent three primary reactions of conversion from a virgin state to an active state, from the active state to char and pyrolyzate gases, and from the active state to tar, and a secondary reaction for breakdown of tar to pyrolyzate. A single step reaction was used for moisture evaporation (Bryden and Hagge 2003). A stoichiometric reaction between methane and air was used to model the combustion of the pyrolyzate gas in FDS.

\section{Abbreviated Results}

As previously stated, details of the fast pyrolysis experiments are presented elsewhere. Preliminary results from the wind tunnel experiments are presented as a poster in this conference (Weise et al. 2018). From the pilot field experiment, fuel loading was dominated by litter and duff ranging from 2.8 to 8.7 and from 3.2 to $10.2 \mathrm{Mg} \mathrm{ha}^{-1}$, respectively. The consumption of the fuel bed categories followed 
similar trends with the most consumption occurring in the litter and duff categories. Fuel moisture content ranged from $8.6 \%$ for the litter to $175.2 \%$ for the shrub fuels bed categories just prior to ignition. It was a challenge in the field to sample the point and time of pyrolysis - the flame is not an even front when it hits the plant but a matrix of different branches catching fire (Figure 58). Also the time of capture for the pyrolysis emissions is short so the actual volume of a good sample is very small. Some of the pyrolysis samples collected had very high $\mathrm{H}_{2}$ and $\mathrm{CO}$ levels indicating that we probably did measure some pyrolysis emissions. These measurements will be compared with the regular smoke samples of flaming combustion that were collected.

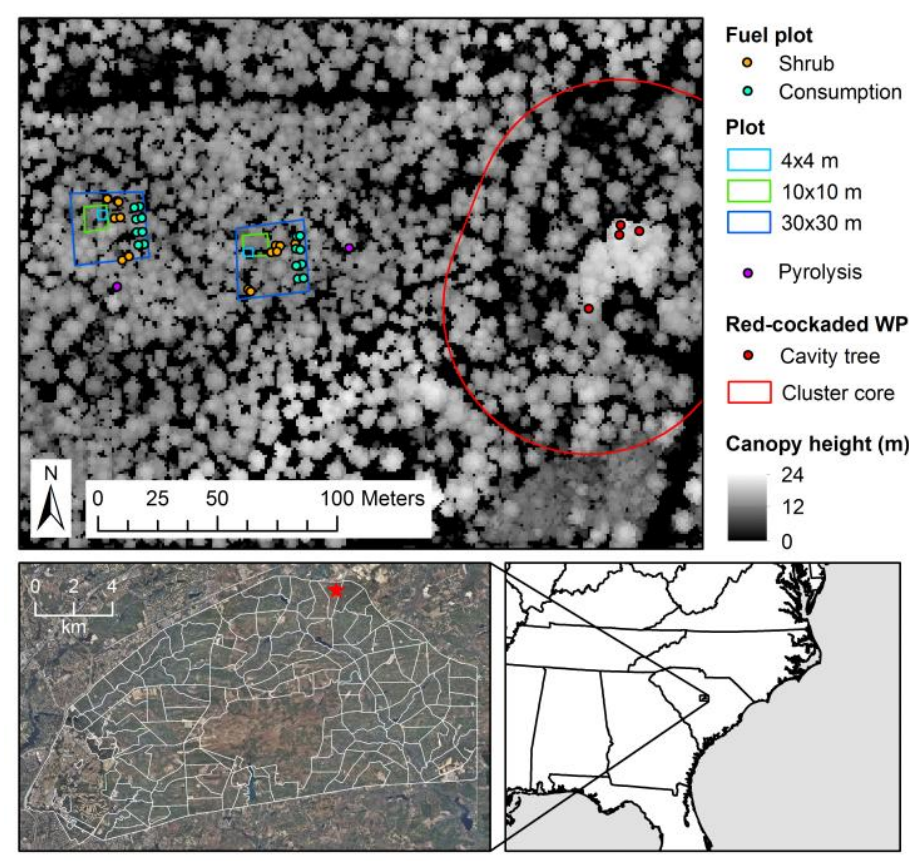

Figure 6 - Individual tree crowns in and around the May 2017 trial deployment plots derived from airborne LiDAR data.

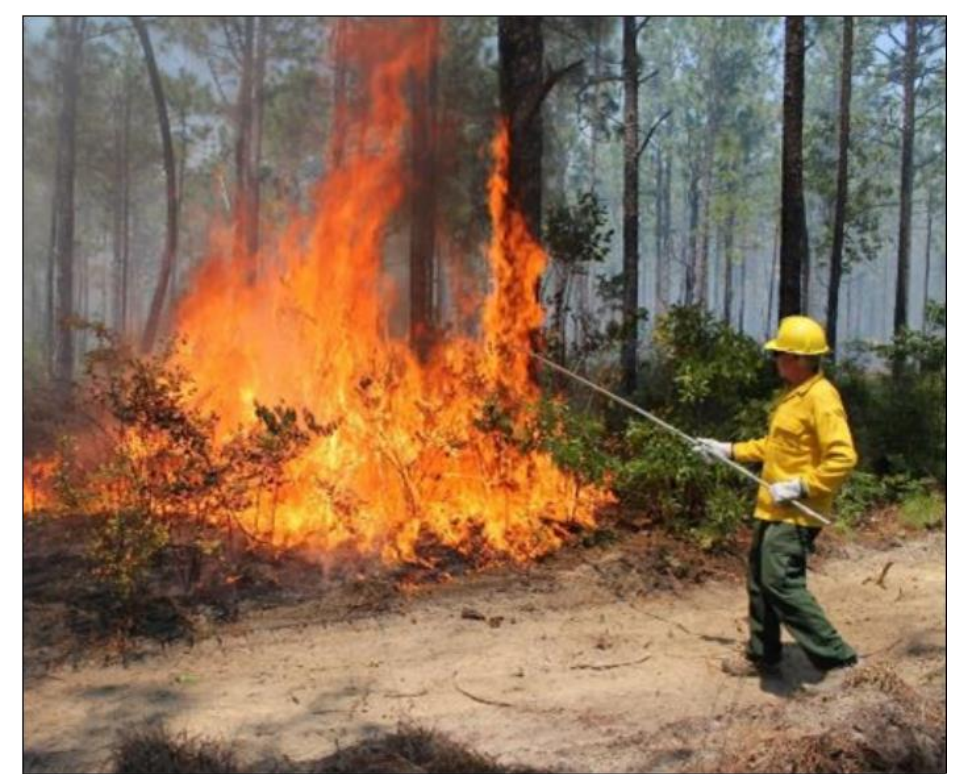

Figure 7 - Rigid tubing ("fishing pole") used to sample pyrolysis gases produced by heated sparkleberry during May 2017 trial deployment at Ft. Jackson, South Carolina, USA. 


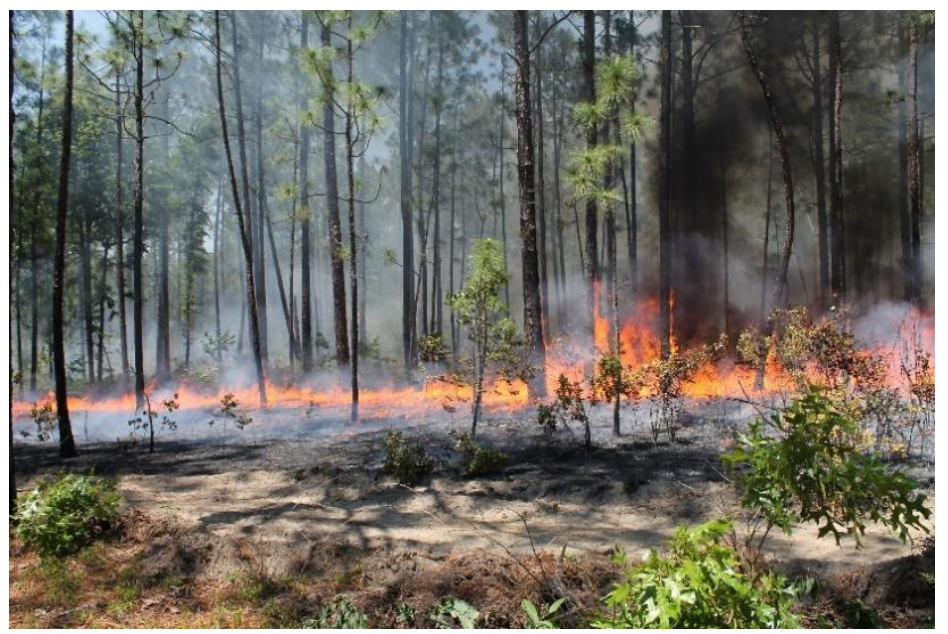

Figure 8 - Typical range in fire behavior observed on low density plot burned May 2017 at Ft. Jackson, SC.

The pyrolysis mechanism included in Gpyro was initially validated against published experimental and computational TGA results. The burning of leaf-like fuels with three initial fuel moisture content (FMC) of $40 \%, 76 \%$, and $120 \%$ was modeled. The time evolutions of the normalized mass were good for the modeled fuels with $76 \%$ and $120 \%$ FMCs and fair for the one with a 40\% FMC when compared to the experimental burning results of four manzanita leaves with unspecified FMCs. The computed ignition time was also in good agreement with the measurement. The computed burnout time was somewhat shorter than the measurement. Modeling revealed the formation of unsteady flow structures including vortices and regions with high strain rates near the fuel that acted as a bluff body against the stream of the burner exit (Figure 59). These structures played a significant role in the spatial distribution of gas phase temperature and species around the fuel, which in turn, had an impact on the ignition location. Fuel moisture content primarily affected the temperature response of the fuel and solid phase decomposition. Full details of these results can be found in (Shotorban et al. 2018).
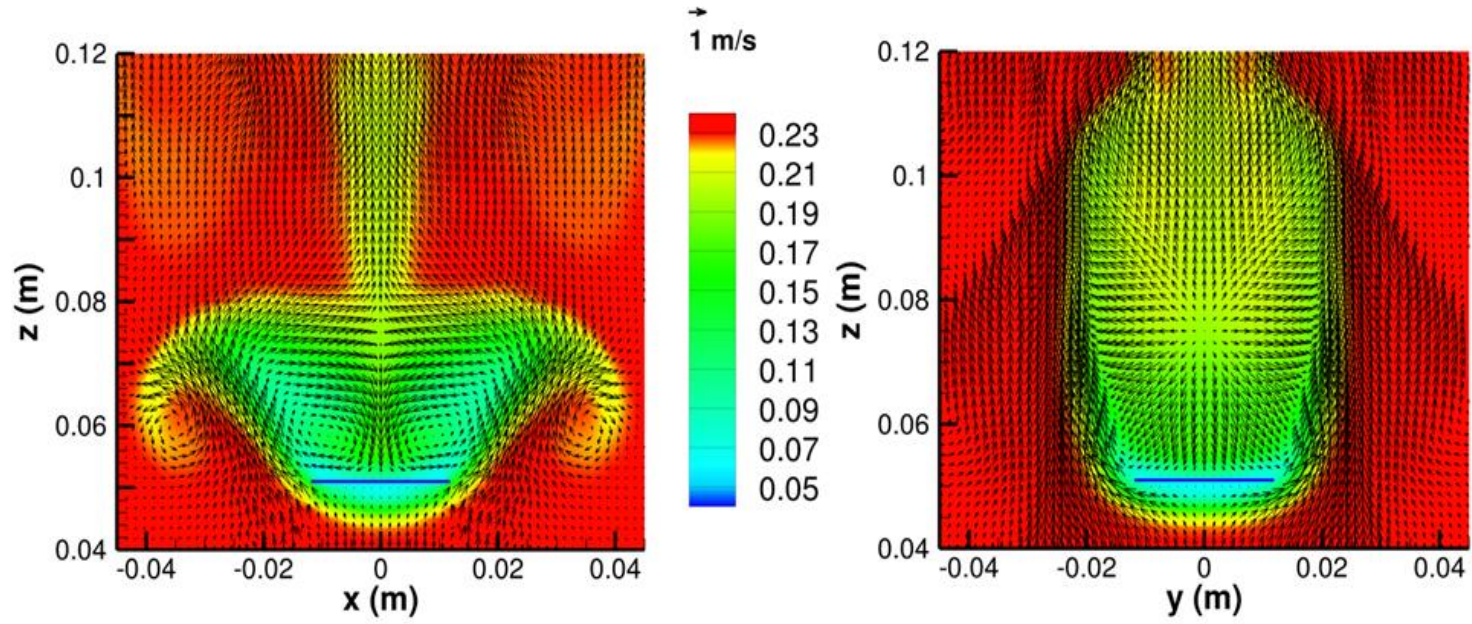

Figure 9 - Contours of oxygen mass fraction and velocity vectors on an $x z$ slice passing $y=0$ (left) and yz slice passing $x=0$ (right) at $t=11.5 \mathrm{~s}$ for an initial FMC of 76\%. See Erro! A origem da referência não foi encontrada. for locations of the slices.

\section{Acknowledgement}

This work was supported was the DOD/EPA/DOE Strategic Environmental Research and Development Program project RC-2640. 


\section{Literature Cited}

Anand C, Shotorban B, Mahalingam S, McAllister S, Weise DR (2017) Physics-based modeling of live wildland fuel ignition experiments in the forced ignition and flame spread test apparatus. Combustion Science and Technology 189, 1551-1570. doi:10.1080/00102202.2017.1308357.

Bryden KM, Hagge MJ (2003) Modeling the combined impact of moisture and char shrinkage on the pyrolysis of a biomass particle tr. Fuel 82, 1633-1644. doi:10.1016/S0016-2361(03)00108-X.

Cobian-Iñiguez J, Aminfar A, Chong J, Burke G, Zuniga A, Weise DR, Princevac M (2017) Wind tunnel experiments to study chaparral crown fires. Journal of Visualized Experiments 1-14. doi:10.3791/56591.

Fletcher TH, Safdari M-S, Amini E, Weise DR (2018) Bench-scale measurement of pyrolysis products from intact live fuels. In 'Adv. For. Fire Res. 2018', Coimbra, Portugal. 3. (Coimbra University Press: Coimbra, Portugal)

Griffith DWT (1996) Synthetic calibration and quantitative analysis of gas-phase FT-IR spectra. Applied Spectroscopy 50, 59-70. doi:10.1366/0003702963906627.

Hudak AT, Bright BC, Pokswinski SM, Loudermilk EL, O’Brien JJ, Hornsby BS, Klauberg C, Silva CA (2016) Mapping Forest Structure and Composition from Low-Density LiDAR for Informed Forest, Fuel, and Fire Management at Eglin Air Force Base, Florida, USA. Canadian Journal of Remote Sensing 42, 411-427. doi:10.1080/07038992.2016.1217482.

Hudak AT, Dickinson MB, Bright BC, Kremens RL, Loudermilk EL, O'Brien JJ, Hornsby BS, Ottmar RD (2016) Measurements relating fire radiative energy density and surface fuel consumption RxCADRE 2011 and 2012. International Journal of Wildland Fire 25, 25-37.

Johnson TJ, Sharpe SW, Covert MA (2006) Disseminator for rapid, selectable, and quantitative delivery of low and semivolatile liquid species to the vapor phase. Review of Scientific Instruments 77, 094103. doi:10.1063/1.2349298.

Mertz L (1967) Auxiliary computation for Fourier spectrometry. Infrared Physics 7, 17-23. doi:10.1016/0020-0891(67)90026-7.

Miller RS, Bellan J (1997) A generalized biomass pyrolysis model based on superimposed cellulose, hemicellulose and liqnin kinetics. Combustion Science and Technology 126, 97-137. doi:10.1080/00102209708935670.

Pickett BM, Isackson C, Wunder R, Fletcher TH, Butler BW, Weise DR (2010) Experimental measurements during combustion of moist individual foliage samples. International Journal of Wildland Fire 19, 153-162. doi:10.1071/WF07121.

Raffel M (2015) Background-oriented schlieren (BOS) techniques. Experiments in Fluids 56,. doi:10.1007/s00348-015-1927-5.

Safdari M-S, Rahmati M, Amini E, Howarth JE, Berryhill JP, Dietenberger M, Weise DR, Fletcher TH (2018) Characterization of pyrolysis products from fast pyrolysis of live and dead vegetation native to the Southern United States. Fuel 229, 151-166. doi:10.1016/j.fuel.2018.04.166.

Shotorban B, Yashwanth BL, Mahalingam S, Haring DJ (2018) An investigation of pyrolysis and ignition of moist leaf-like fuel subject to convective heating. Combustion and Flame 190, 25-35. doi:10.1016/j.combustflame.2017.11.008.

Silva CA, Hudak AT, Vierling LA, Loudermilk EL, O’Brien JJ, Hiers JK, Jack SB, Gonzalez-Benecke C, Lee H, Falkowski MJ, Khosravipour A (2016) Imputation of individual longleaf pine ( Pinus palustris Mill.) tree attributes from field and LiDAR data. Canadian Journal of Remote Sensing $\mathbf{4 2}$, 554-573. doi:10.1080/07038992.2016.1196582.

Weise DR, Johnson TJ, Hao WM, Princevac M, Scharko N, Oeck A, Myers TL, Baker S, Lincoln E, Aminfar AH (2018) Measurement of pyrolysis products from mixed fuel beds during fires in a wind 
tunnel. In 'Adv. For. Fire Res. 2018', Coimbra, Portugal.(Coimbra University Press: Coimbra, Portugal)

Yashwanth BL, Shotorban B, Mahalingam S, Lautenberger CW, Weise DR (2016) A numerical investigation of the influence of radiation and moisture content on pyrolysis and ignition of a leaflike fuel element. Combustion and Flame 163, 301-316. doi:10.1016/j.combustflame.2015.10.006.

Yashwanth BL, Shotorban B, Mahalingam S, Weise DR (2015) An investigation of the influence of heating modes on ignition and pyrolysis of woody wildland fuel. Combustion Science and Technology 187, 780-796. doi:10.1080/00102202.2014.973948.

Yokelson RJ, Griffith DWT, Ward DE (1996) Open-path Fourier transform infrared studies of largescale laboratory biomass fires. Journal of Geophysical Research 101, 21067. doi:10.1029/96JD01800.

Zhou X, Sun L, Mahalingam S, Weise DR (2003) Thermal particle image velocity estimation of fire plume flow. Combustion Science and Technology 175, 1293-1316. doi:10.1080/00102200302376. 